\title{
Inovasi Pemberdayaan Ekonomi Pada UKM Jamu Rumah Herbal Mak Nyak di Kabupaten Jember
}

\author{
Fefi Nurdiana Widjayanti ${ }^{1^{*}}$, Trias Setyowati ${ }^{2}$ \\ ${ }^{1}$ Prodi Agribisnis Fakultas Pertanian, Universitas Muhammadiyah Jember \\ ${ }^{2}$ Prodi Manajemen Fakultas Ekonomi ${ }^{2}$ Universitas Muhammadiyah Jember \\ 11 fefinurdiana@unmuhjember.ac.id, 2trias@unmuhjember.ac.id
}

\begin{abstract}
The current pandemic condition raises the need to always maintain health and body immunity to be of utmost priority. Herbal medicine as a form of traditional medicine plays an important role in the treatment of population in developing countries, especially Indonesia. The majority of traditional herbal medicine businesses are carried out by home-based business groups, such as traditional herbal medicine businesses carried out by groups of women in Dasa Wisma Aster Dahlia who are domiciled at Tegalbesar Village, Kaliwates District, Jember Regency, produced among others: Jamu Temulawak, Jamu Kunci Sirih, Jamu Kunyit Asem and Jamu Beras Kencur, the herbal medicine which is produced is made from "empon empon" as the base ingredient which is quite abundant in Jember Regency. Herbal medicine business has a very good potential to be developed, because the market demand is very high so that if it is pursued more seriously, it can be used to support the economy of Dama's members. Team acts as: (1) Presenters of socialization, initiator and signing of the MOU document between the two parties, (2) Trainer or assistant for production, monitoring and evaluation (monev) ) post production, packaging and labeling of the final product. Delivering material in the form of lectures, discussions and questions and answers, practice and supervision, continuous monitoring and evaluation to achieve self-sufficiency in production with good product quality. Dama's members as a socialization participant, also acts as a training participant and mentors the production, marketing, packaging and labeling of the final product.
\end{abstract}

Keywords: Empowerment, Herbs, Innovation, Jamu, Traditional Herbal Medicine

\begin{abstract}
Abstrak
Kondisi pandemi yang saat ini terjadi memunculkan kebutuhan, untuk selalu menjaga kesehatan dan imunitas tubuh menjadi hal yang sangat diutamakan, Jamu (herbal medicine) sebagai salah satu bentuk pengobatan tradisional, memegang peranan penting dalam pengobatan penduduk di negara berkembang khususnya Indonesia. Usaha jamu tradisional mayoritas dilakukan oleh UMKM atau kelompok-kelompok usaha rumahan, seperti usaha jamu tradisional yang dilakukan oleh kelompok ibu- ibu di Dasa Wisma Aster Dahlia yang berdomisili di Kelurahan Tegalbesar, Kecamatan Kaliwates, Kabupaten Jember, produk jamu yang diproduksi antara lain : Jamu Temulawak,Jmu Kunci Sirih, Jamu Kunyit Asem dan Jamu Beras Kencur, jamu yang diproduksi terbuat dari bahan dasar empon empon yang tersedia cukup melimpah di Kabupaten Jember. Usaha jamu empon empon dama "Aster Dahlia" ini memiliki potensi yang sangat bagus untuk dikembangkan, karena permintaan pasar sangat tinggi sehingga jika ditekuni secara lebih serius akan dapat dipergunakan untuk menopang ekonomi anggota Dama. Tim Pelaksana bertindak sebagai : (1) Pemateri sosialisasi, pemerakarsa dan penandatanganan dokumen MOU antara kedua belah pihak, (2) Pelatih atau Pendamping kegiatan produksi, monitoring dan evaluasi (monev) pasca kegiatan produksi, pengemasan dan pelabelan produk akhir. Penyampaian materi dalam bentuk ceramah, diskusi dan tanya jawab, praktek dan supervisi, monitoring dan evaluasi berkelanjutan untuk mencapai kemandirian dalam produksi dengan mutu produk yang baik. Mitra Ibu Ibu Dasa Wisma (Dama) "Aster Dahlia" sebagai peserta sosialisasi, juga bertindak sebagai peserta pelatihan dan pendampingan proses produksi, pemasaran, pengemasan dan pelabelan produk akhir.
\end{abstract}

Kata Kunci : Herbal, Inovasi, Jamu, Jamu Tradisional, Pemberdayaan

*Penulis Korespondensi : Fefi Nurdiana Widjayanti

http://comdev.pubmedia.id | Indonesian Journal Publisher | https://idpublishing.org 


\section{PENDAHULUAN}

Jamu merupakan warisan budaya bangsa Indonesia, berupa ramuan bahan tumbuhan obat, sudah digunakan secara turun temurun yang terbukti aman dan mempunyai manfaat bagi kesehatan. Jamu dapat digunakan untuk menjaga kesehatan, kebugaran dan kecantikan serta dapat membantu pemulihan kesehatan dan pencegahan penyakit (Kementrian Kesehatan RI, 2015).

Jamu di Indonesia biasa digunakan sebagai obat herbal atau hasil meramu bahan-bahan yang berasal dari alam dan memiliki khasiat untuk kesehatan. Jamu tidak hanya berfungsi sebagai obat, tetapi juga untuk menjaga kebugaran tubuh dan mencegah dari penyakit. Jamu juga biasa digunakan untuk membantu meningkatkan nafsu makan bagi anak-anak. Jamu juga dapat disebut obat rumahan karena biasanya dibuat sendiri di rumah dari bahan-bahan yang ada di sekitar, yaitu kunyit, kencur, jahe, lengkuas, dan jenis rimpang atau tanaman lainnya. Indonesia memiliki kekayaan hayati melimpah yang biasa dijadikan bahan-bahan untuk mengolah jamu. Akan tetapi, ada jenis tanaman yang merupakan bahan utama untuk membuat jamu yang biasa dikonsumsi. Tanaman tersebut merupakan anggota keluarga Zingerberaceae. Beberapa jenis tanaman yang termasuk dalam keluarga ini adalah jahe, kunyit, kencur, dan lengkuas. Tanaman ini memiliki khasiat masing-masing dan diolah menjadi beberapa jenis jamu yang berbeda (Army, 2018).

Untuk menyelenggarakan Program Peningkatan Diversifikasi dan Ketahanan Pangan Masyarakat, maka akan dilaksanakan 4 (empat) kegiatan sesuai dengan tugas dan fungsi Badan Ketahanan Pangan yang meliputi:

1. Pengembangan Ketersediaan dan Penanganan Rawan Pangan;

2. Pengembangan Sistem Distribusi dan Stabilitas Harga Pangan;

3. Pengembangan Penganekaragaman Konsumsi Pangan dan Keamanan Pangan;

4. Dukungan Manajemen dan Teknis Lainnya pada Badan Ketahanan Pangan (Badan Ketahanan Pangan, 2019).
UKM Rumah Herbal Mak Nyak adalah salah satu usaha kecil dari kelompok ibu-ibu yang bertujuan memberdayakan anggota Dasa Wisma Aster Dahlia dengan wirausaha Jamu dengan memanfaatkan sumber daya lokal. UKM Jamu tersebut merupakan salah satu dari kegiatan sesuai tugas dan fungsinya pada Badan Ketahanan Pangan yaitu Pengembangan Penganekaragaman Konsumsi Pangan Dan Keamanan Pangan.

Usaha jamu tradisional empon empon yang sudah dirintis sejak tahun 2019 adalah yang dilakukan oleh kelompok ibu-ibu Dasa Wisma Asliya yang berlokasi di Perum Bumi Tegal Besar Blok Di, RT. 01, RW. 44 kelurahan Tegalbesar, kecamatan Kaliwates, kabupaten Jember salah satu sentra usaha kecil Jamu Tradisional yang dikelola oleh kelompok Ibu-Ibu Dasa Wisma Aster Dahlia yang diketuai oleh Ibu Dewi Jatiningsih, Fungsi kelompok Dasa Wisma ini adalah sebagai penggerak dan pembina masyarakat di lingkungannya untuk turut mensukseskan pelaksanaan program pokok PKK, guna peningkatan pemberdayaan perempuan, implementasi dari kegiatan Dasa Wisma melalui usaha pembuatan jamu dari empon empon ini menjadi upaya peningkatan ekonomi keluarga.

Keterbatasan pengetahuan, modal dan peralatan yang masih sangat sederhana dalam memproduksi jamu, telah membuat ibu-ibu Dasa Wisma Aster Dahlia tidak bisa menghasilkan produksi dengan jumlah yang banyak sesuai permintaan pasar dan mutu produksi yang kurang baik serta keterbatasan jaringan pemasaran. Berdasarkan analisis situasi pada mitra, dapat dirumuskan empat permasalahan prioritas yang telah disepakati bersama mitra sebagai berikut.

1) Pemasaran masih konvensional di sekitar perumahan dan penyajian masih menggunakan gelas.

2) Pemasaran masih dilakukan secara door to door.

3) Belum memiliki label kemasan sehingga tidak memiliki daya saing dengan produk sejenis, hal ini sangat disayangkan karena peluang untuk bisa mendapatkan keuntungan menjadi hilang

4) Belum dapat menghitung keuangan dan membuat laporan keuangan sederhana. 
Dalam pengembangan jamu tanaman obat menjadi produk maka tentu dibutuhkan kerjasama pemerintah, Universitas dan dunia usaha. Pengembangan Tanaman Obat sebagai Jamu Tradisional: 1. Pembinaan terhadap standarisasi bahan baku. 2. Pembinaan terhadap cara pembuatan jamu yang baik. 3. Pembinaan terkait penggunaan jamu yang aman dan rasional. 4. Lebih diarahkan pada penggunaan menjaga kesehatan dan pencegahan penyakit (Aditama, no date).

Berdasarkan permasalahan prioritas dari mitra maka solusi pertama yang ditawarkan dalam kegiatan PKM ini adalah pembelian botol kemasan dan panci besar agar dapat membantu produksi jamu untuk meningkatkan jumlah penjualan dan menambah pendapatan. Target Luaran dari solusi pertama adalah (1) kemasan menjadi lebih hygienis (2) memudahkan dan terbantu dalam berproduksi jamu dengan kapasitas alat yang lebih besar (3)menarik minat pembeli dengan adanya kemasan botol .

Solusi untuk permasalahan yang kedua adalah program pelatihan dan pendampingan produksi jamu tradisional, pengemasan dan pelabelan produk. Target luaran dari solusi pertama adalah (1) Pengetahuan dan kesadaran dari mitra tentang pentingnya kerjasama kemitraan yang tertuang dalam dokumen kesepakatan (MOU) (2) Tersedianya kemasan produk yang tahan lama, aman dan menarik minat konsumen, (3) Tersedianya pelabelan.

Solusi ketiga yang ditawarkan adalah program dan model pemasaran berbasis jaringan on line, serta pendampingan dalam penerapannya. Pemasaran merupakan aktifitas yang bertujuan untuk mengidentifikasi dan menemukan kebutuhan manusia. Secara ringkas pemasaran bisa diartikan dengan sebagai "meeting needs profitably" yaitu bagaimana perusahaan bisa melayani kebutuhan konsumen dengan cara yang menguntungkan bagi konsumen dan perusahaan. Misalnya saat ini, banyak orang yang karena kesibukan menjadi tidak punya banyak waktu untuk melakukan pemilihan dan pembelian barang dengan cara mendatangi satu per satu toko, maka perdagangan online tumbuh subur untuk melayani jenis konsumen seperti ini (Rahmawati, 2016). Strategi pemasaran perlu dibangun banyak kerjasama dengan agen-agen penjualan ritel lokal dan nasional serta unsur pemerintah dan perbankan di Kabupaten Jember dan sekitarnya, serta keikutsertaan dalam event pameran produk-produk UMKM.

Target luaran dari solusi kedua adalah (1) Tersedianya model pemasaran berbasis jaringan on line dan penerapannya dalam bentuk kerjasama dengan agen penjualan ritel lokal seperti restoran dan toko pusat oleh-oleh khas daerah (2) Tersedianya model promosi berbasis on line yang dipasang pada kemasan produk dan iklan promosi, (3) Terbangunnya akses pembinaan dari pemerintah daerah dan permodalan dari perbankan melalui skema pinjaman lunak KUR untuk pengembangan kapasitas usaha dan produk, (4) Peningkatan omzet dan kuantitas penjualan produk jamu tradisional dalam setiap periode pemasaran sehingga terjadi peningkatan pendapatan anggota mitra.

Solusi keempat yang ditawarkan adalah pelatihan pembuatan laporan keuangan sederhana sehingga dapat menjadi acuan dan pelajaran bagi mitra untuk mengambil keputusan dalam memproduksi jamunya. Masalah-masalah keahlian, sampai sekarang dikejar orang dalam berbagai sekolah atau pendidikan.

Adapun keahlian pokok yang perlu dimiliki oleh seorang wirausaha atau siapa saja adalah :

a) Keahlian pengendalian keuangan;

b) Keahlian mengenai risiko persaingan;

c) Keahlian mengurus usaha atau manajemen usaha;

d) Keahlian menawarkan produk (salesmanship); dan

e) Keahlian menjaga hubungan dengan pelanggan (Prof. Dr. Abdul Muin Sibuea and Drs. Dadang Mulyana, 2018).

Target Luarannya adalah (1) mitra dapat membuat laporan sederhana (2) dapat mengambil keputusan dalam hal jumlah dan biaya produksi dengan melihat hasil laporan keuangan. 


\section{METODE}

Berikut ini gambar yang menunjukkan tahapantahapan yang dilakukan pada pelaksanaan kegiatan pengabdian kepada masyarakat :

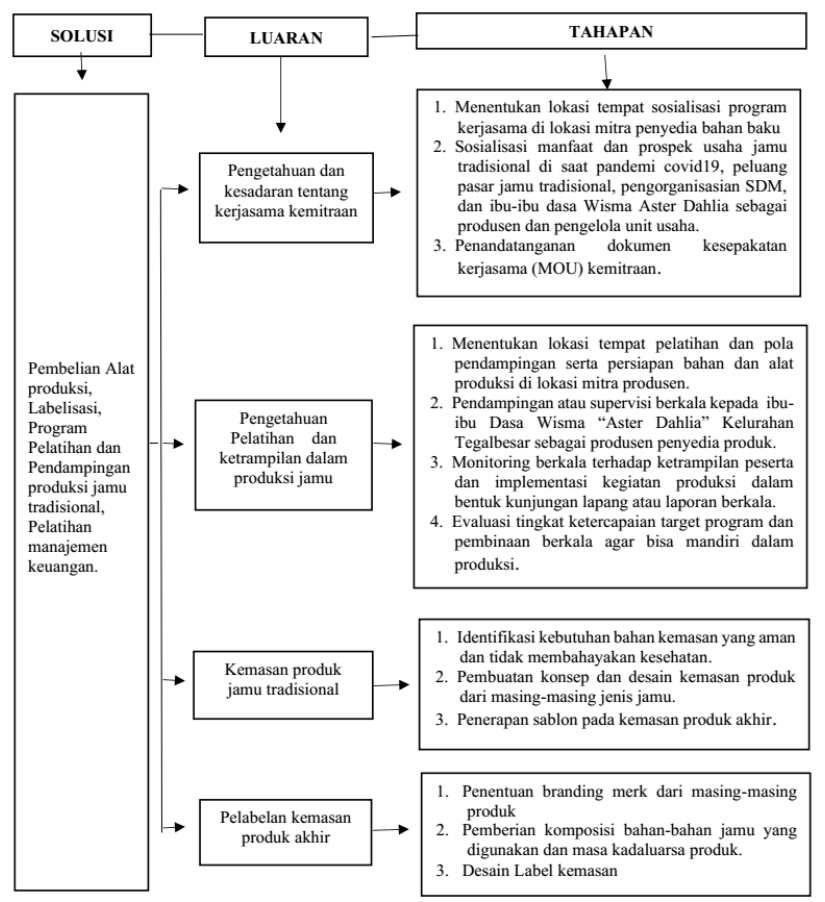

Gambar 1. Tahapan Pelaksanaan Kegiatan Pengabdian

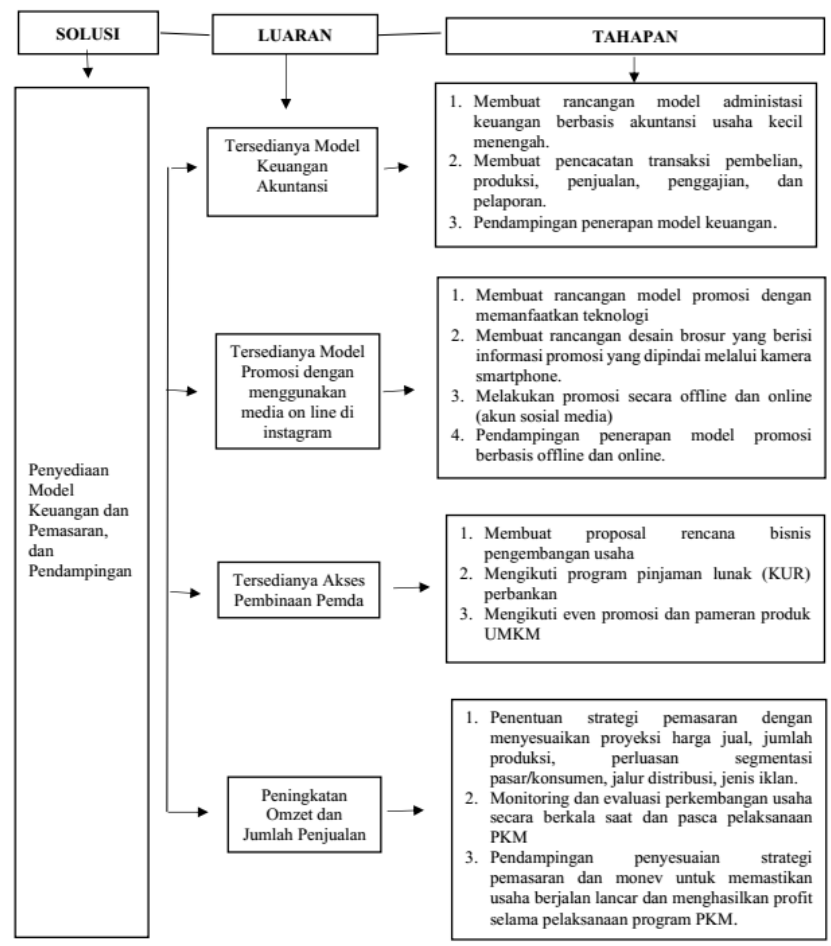

Gambar 2. Tahapan Manajemen Keuangan dan Pemasaran

\section{HASIL DAN PEMBAHASAN}

\section{A. Peserta Pengabdian dan Pelatihan}

Mitra dalam hal ini adalah Ibu-ibu Dama Aster Dahlia di Kecamatan Kaliwates Kabupaten Jember, yang lokasi pembuatan Jamunya berada di Perumahan Bumi Tegal Besar Blok DI No.26. Penyampaian materi dalam bentuk ceramah, diskusi dan tanya jawab, praktek dan supervisi, monitoring dan evaluasi berkelanjutan untuk mencapai kemandirian dalam produksi dengan mutu produk yang baik. Mitra Ibu Ibu Dasa Wisma (Dama) "Aster Dahlia" sebagai peserta sosialisasi, juga bertindak sebagai peserta pelatihan dan pendampingan proses produksi, pemasaran, pengemasan dan pelabelan produk akhir. Dalam program pelatihan dan pendampingan produksi jamu tradisional, pengemasan dan pelabelan produk akhir.

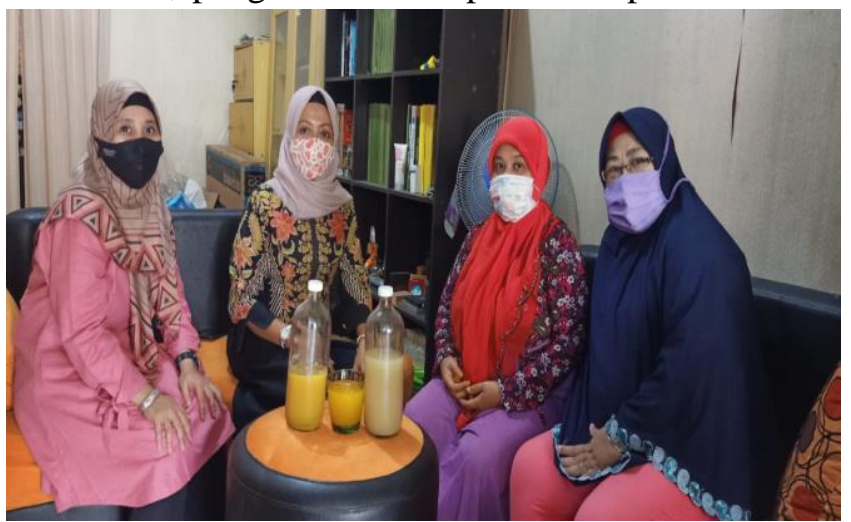

Gambar 3. Tim Pelaksana dan Mitra

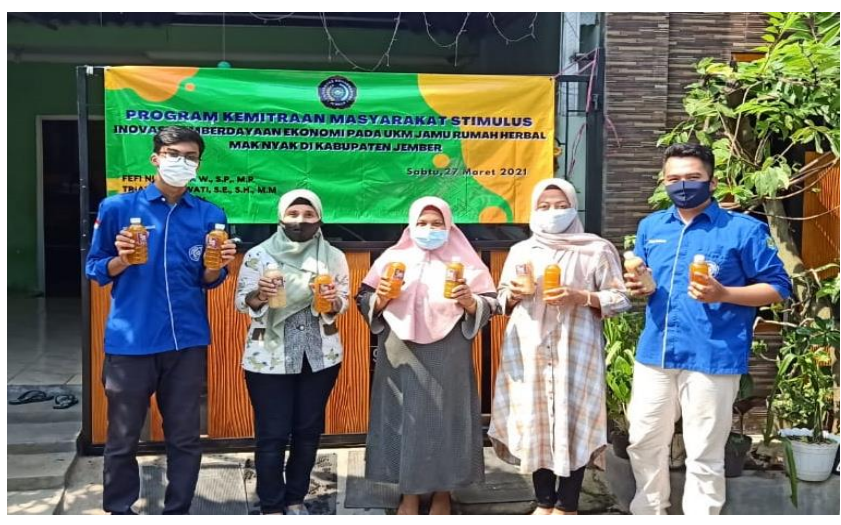

Gambar 4. Tim Pelaksana, Mahasiswa dan Mitra

\section{B. Jenis Luaran yang Dihasilkan}

Jenis luaran yang akan dihasilkan sesuai dengan rencana kegiatan adalah :

1. Pembelian bantuan berupa: 
$>$ Botol kemasan dan panci besar
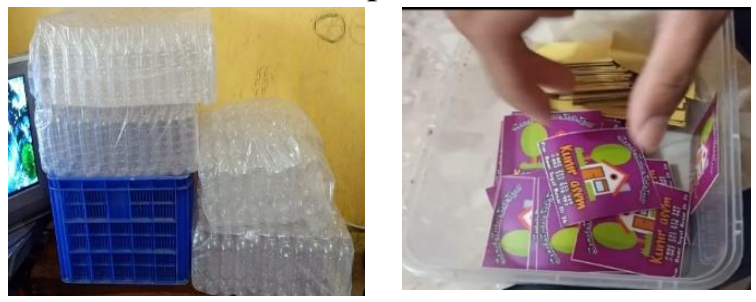

Gambar 5. Bantuan Kemasan
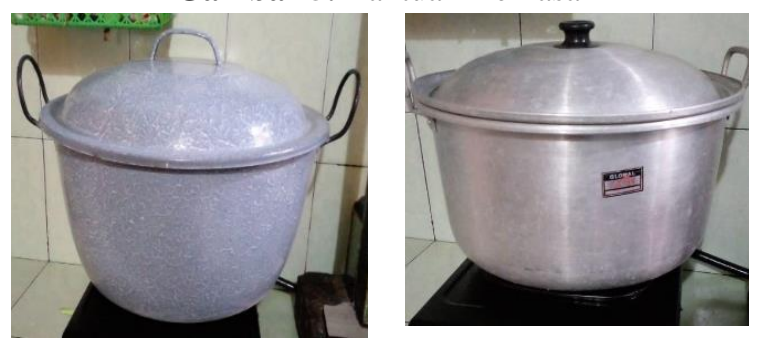

Gambar 6. Bantuan Panci Besar
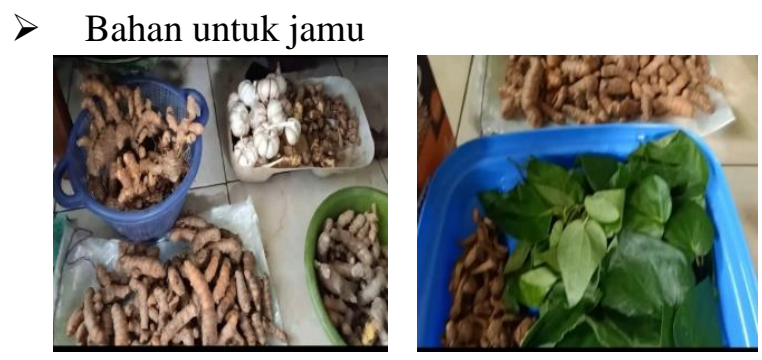

Gambar 7. Bantuan Bahan untuk Jamu

2. Produk Jamu yang sudah ber label

3. Mempunyai media on line untuk promosi

4. Publikasi ilmiah di Jurnal Pengabdian LPPM UM Jember.

5. Publikasi di media elektronik Suara Indonesia.

6. Publikasi di youtube pelaksana

\section{Spesifikasi Produk}

Pelatihan atau Pendampingan pada kegiatan produksi, monitoring dan evaluasi (monev) kegiatan produksi, pengemasan dan pelabelan produk akhir produk Jamu tradisional. Yang bertujuan untuk mencapai kemandirian dalam produksi dengan mutu produk yang lebih baik. Produk yang dihasilkan lebih hygienis, produk yang tahan lama, aman dan menarik minat konsumen. Produk mempunyai label pada kemasan sehingga mudah dikenal dan memudahkan dalam menambah konsumen. Produk dipromosikan pada media online (Instagram).
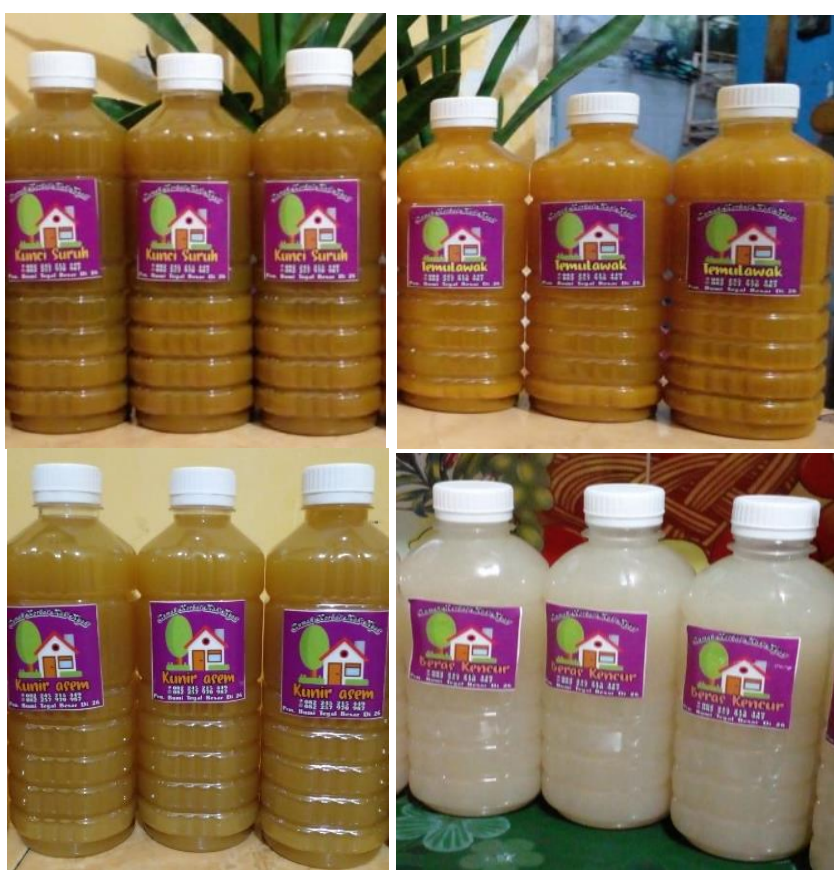

Gambar 8. Produk Jamu Herbal Rumah Mak Nyak

\section{Luaran dan Target Capaian}

Luaran dan target capaian kegiatan pengabdian kepada masyarakat dengan judul Inovasi Pemberdayaan Ekonomi pada UKM Rumah Herbal Mak Nyak di Kabupaten Jember akan di Published di Jurnal Pengabdian LPPM UM Jember, Media Cetak Elektronik Suara Indonesia dan di Youtube Channel Ketua Pelaksana, secara rinci ditunjukkan dalam Tabel 1.

Tabel 1. Target Capaian Luaran

\begin{tabular}{|c|c|c|c|c|c|}
\hline \multirow[b]{2}{*}{ NO } & \multicolumn{4}{|c|}{ Jenis Luaran } & \multirow{2}{*}{$\begin{array}{c}\begin{array}{c}\text { Indikato } \\
\mathbf{r}\end{array} \\
\text { Capaian } \\
\text { TS }\end{array}$} \\
\hline & Kategori & $\begin{array}{c}\text { Sub } \\
\text { Kategori }\end{array}$ & $\begin{array}{c}\text { Waji } \\
\text { b }\end{array}$ & $\begin{array}{c}\text { Tam } \\
\text { baha } \\
\mathbf{n}\end{array}$ & \\
\hline \multirow[b]{2}{*}{1} & \multirow{2}{*}{$\begin{array}{c}\text { Artikel } \\
\text { ilmiah di } \\
\text { jurnal } \\
\text { LPPM } \\
\text { UM } \\
\text { Jember }\end{array}$} & $\begin{array}{l}\text { Nasional } \\
\text { Terakreditas } \\
\mathrm{i}\end{array}$ & $\sqrt{ }$ & & Published \\
\hline & & $\begin{array}{l}\text { Nasional } \\
\text { Tidak } \\
\text { Terakreditas } \\
\text { i }\end{array}$ & & & \\
\hline \multirow{2}{*}{2} & \multirow{2}{*}{$\begin{array}{c}\text { Artikel } \\
\text { Koran di }\end{array}$} & Nasional & & & \\
\hline & & Lokal & $\sqrt{ }$ & & Draf \\
\hline
\end{tabular}




\begin{tabular}{|c|c|c|c|c|c|}
\hline \multirow{3}{*}{ NO } & \multicolumn{4}{|c|}{ Jenis Luaran } & \multirow{2}{*}{$\begin{array}{c}\begin{array}{c}\text { Indikato } \\
\mathbf{r} \\
\text { Capaian }\end{array} \\
\text { TS }\end{array}$} \\
\hline & Kategori & $\begin{array}{c}\text { Sub } \\
\text { Kategori }\end{array}$ & $\begin{array}{c}\text { Waji } \\
\text { b }\end{array}$ & $\begin{array}{c}\text { Tam } \\
\text { baha } \\
\mathbf{n}\end{array}$ & \\
\hline & $\begin{array}{c}\begin{array}{c}\text { Media } \\
\text { Masa }\end{array} \\
\text { https://sua } \\
\text { raindonesi } \\
\underline{\text { a.co.id/ }}\end{array}$ & & & & \\
\hline 3 & $\begin{array}{c}\begin{array}{c}\text { Media } \\
\text { https://ww }\end{array} \\
\underline{\text { w.youtube }} \\
\frac{. \text { com/watc }}{\text { h?v=Zw6e }} \\
\underline{\text { Co-bdxc }}\end{array}$ & $\begin{array}{l}\text { Video } \\
\text { Kegiatan }\end{array}$ & $\sqrt{ }$ & & Ada \\
\hline \multirow{5}{*}{4} & \multirow{5}{*}{$\begin{array}{l}\text { Peningkat } \\
\text { an Daya } \\
\text { Saing }\end{array}$} & Kualitas & & & \\
\hline & & Kuantitas & & & \\
\hline & & $\begin{array}{l}\text { Nilai } \\
\text { Tambah } \\
\text { Barang/Jasa }\end{array}$ & $\sqrt{ }$ & & Produk \\
\hline & & $\begin{array}{l}\text { Diversikasi } \\
\text { Produk }\end{array}$ & & & \\
\hline & & $\begin{array}{l}\text { Sumber } \\
\text { Daya } \\
\text { Lainnya }\end{array}$ & & & \\
\hline \multirow{3}{*}{5} & \multirow{3}{*}{$\begin{array}{c}\text { Peningkat } \\
\text { an } \\
\text { Penerapan } \\
\text { IPTEKS }\end{array}$} & Mekanisasi & & & \\
\hline & & $\begin{array}{l}\text { Teknologi } \\
\text { Informasi }\end{array}$ & & & \\
\hline & & Manajemen & $\sqrt{ }$ & & Penerapan \\
\hline \multirow{7}{*}{6} & \multirow{7}{*}{$\begin{array}{c}\text { Perbaikan } \\
\text { Tata Nilai } \\
\text { Masyarak } \\
\text { at }\end{array}$} & Seni Budaya & $\sqrt{ }$ & & Ada \\
\hline & & Sosial & $\sqrt{ }$ & & Ada \\
\hline & & Politik & & & \\
\hline & & Keamanan & & & \\
\hline & & $\begin{array}{l}\text { Ketentrama } \\
\mathrm{n}\end{array}$ & & & \\
\hline & & Pendidikan & $\sqrt{ }$ & & Ada \\
\hline & & Kesehatan & & & \\
\hline 7 & \multicolumn{2}{|c|}{ Teknologi Tepat Guna } & & & Tidak ada \\
\hline 8 & \multicolumn{2}{|c|}{$\begin{array}{l}\text { Barang/Jasa/Rekayasa/Me } \\
\text { tode/Sistem/Produk }\end{array}$} & $\sqrt{ }$ & & Produk \\
\hline 9 & \multicolumn{2}{|c|}{ Buku (ISBN) } & & & Tidak ada \\
\hline
\end{tabular}

Berikut ini data luaran yang telah dipublikasikan pada media online :
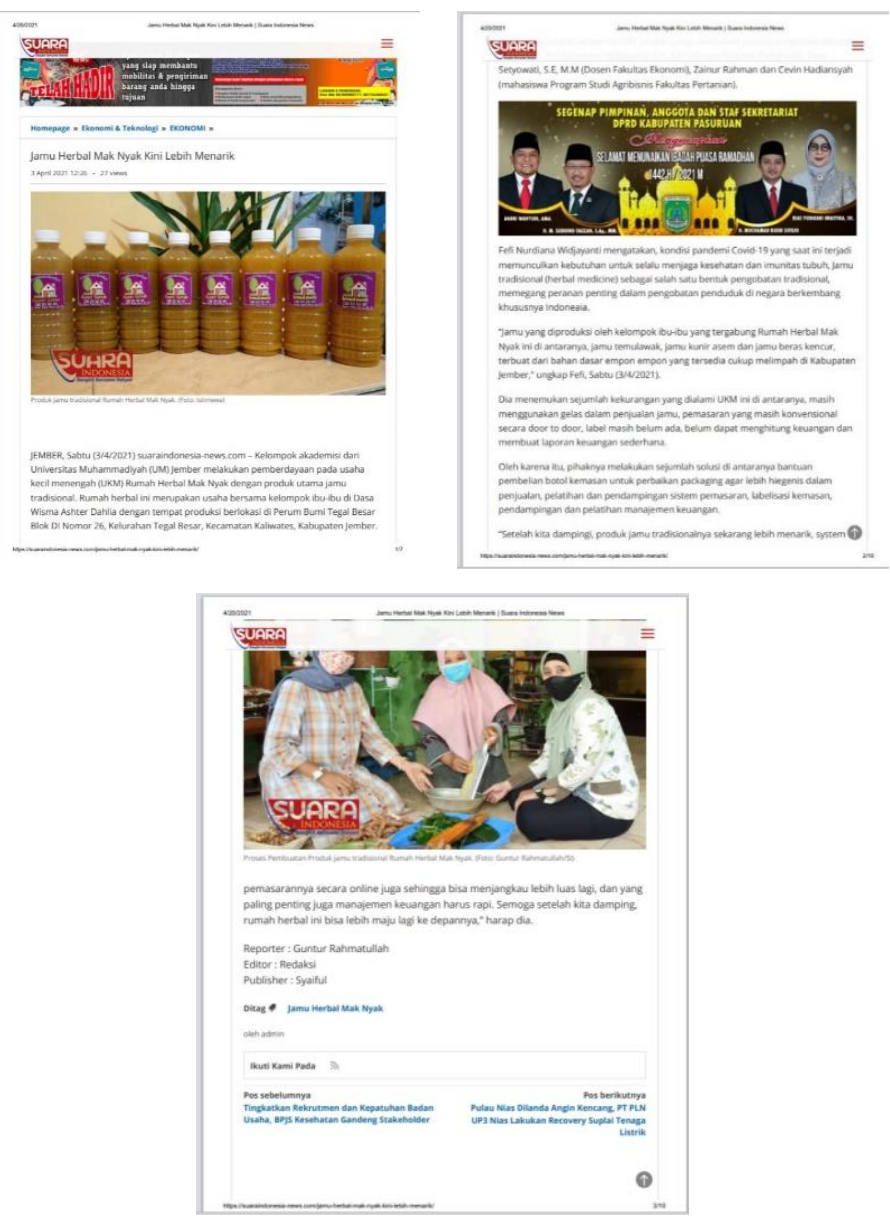

Gambar 9. Artikel On line di Media Suara Indonesia https://suaraindonesia-news.com/jamu-herbal-mak-nyak-kinilebih-menarik/

Sedangkan gambar dibawah ini menunjukkan hasil kegiatan yang diupload pada youtube :
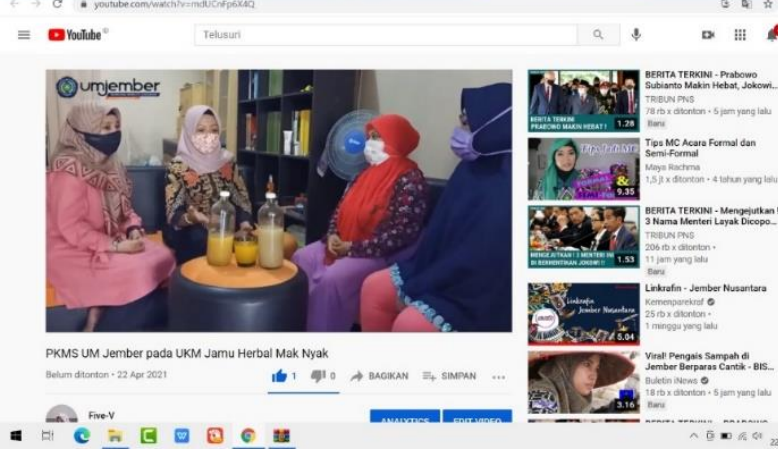

Gambar 10. Unggah di Media sosial Youtube Pelaksana https://www.youtube.com/watch?v=Zw6eCo-bdxc 


\section{KESIMPULAN}

Kesimpulan dari kegiatan program kemitraan masyarakat ini adalah untuk menerapkan salah satu unsur Tri Darma Perguruan Tinggi yaitu : (1) Tim Pelaksana telah melaksanakan kegiatan pengadaan bahan dan alat untuk pembuatan jamu tradisional untuk kemitraan kepada masyarakat dan (2) Kegiatan Kemitraan kepada Masyarakat ini untuk menambah pendapatan bagi ibu-ibu Dama Aster Dahlia agar mandiri secara ekonomi (3) Luaran dari hasil pengabdian ini dapat dijadikan sebagai solusi untuk meningkatkan mutu produk, aman, hygienis dan tahan lama. Saran untuk pemerintah adalah terus memberikan peluang kepada pelaku usaha untuk diberdayakan di perusahaan yang sudah mempunyai pangsa pasar. Dukungan dapat berupa pelatihan pelatihan untuk mengembangkan usaha dan permodalan.

\section{UCAPAN TERIMA KASIH}

Ucapan terima kasih disampaikan kepada LPPM Universitas Muhammadiyah Jember, Mitra
Dama Aster Dahlia dan semua pihak yang telahbanyak membantu penyelesaian pengabdian ini.

\section{DAFTAR PUSTAKA}

Aditama, T. Y. (no date) Prof dr Tjandra Yoga Aditama.

Army, Ri. (2018) Jamu Ramuan Tradisional Kaya Manfaat. Available at: http://badanbahasa.kemdikbud.go.id/lamanbahasa/site s/default/files/Jamu, Ramuan Tradisional Kaya Manfaat-Rifqa-Final.pdf.

Badan Ketahanan Pangan (2019) 'Rencana Kinerja Tahunan Badan Ketahanan Pangan Tahun 2020', pp. 1-21.

Kementrian Kesehatan RI (2015) 'Pembuatan Jamu Segar Yang Baik dan Benar', Journal of Chemical Information and Modeling, 53(9), pp. 1689-1699. Available http://dx.doi.org/10.1016/j.tws.2012.02.007.

Prof. Dr. Abdul Muin Sibuea, M. P. and Drs. Dadang Mulyana, M. P. (2018) Pengantar Kewirausahaan Dalam Meningkatkan Pemahaman Kewirausahaan.

Rahmawati (2016) 'Manajemen Pemasaran', University Mulawarman, pp. 4-5. 